\title{
The Potential of Activated Carbon in the Treatment of Water for Human Consumption, a Study of the State of the Art and Its Techniques Used for Its Development
}

\author{
Adenes Teixeira Alves ${ }^{*}$, Dimas José Lasmar ${ }^{1}$, Ires Paula de Andrade Miranda², \\ Jamal da Silva Chaar ${ }^{1}$, Jardson dos Santos Reis ${ }^{1}$ \\ ${ }^{1}$ Federal University of Amazonas-UFAM, Manaus, Amazonas, Brazil \\ ${ }^{2}$ National Institute for Amazon Research (INPA), Manaus, Amazonas, Brazil \\ Email: ^professoradenes@hotmail.com,dimas.lasmar@gmail.com, ires@inpa.gov.br, jchaar@gmail.com, jardsonreis@ufam.edu.br
}

How to cite this paper: Alves, A.T., Lasmar, D.J., de Andrade Miranda, I.P., da Silva Chaar, J. and dos Santos Reis, J. (2021) The Potential of Activated Carbon in the Treatment of Water for Human Consumption, a Study of the State of the Art and Its Techniques Used for Its Development. Advances in Bioscience and Biotechnology, 12, 143-153. https://doi.org/10.4236/abb.2021.126010

Received: May 3, 2021

Accepted: June 8, 2021

Published: June 11, 2021

Copyright ( 2021 by author(s) and Scientific Research Publishing Inc. This work is licensed under the Creative Commons Attribution International License (CC BY 4.0).

http://creativecommons.org/licenses/by/4.0/

\begin{abstract}
This review article addresses the use of biological activated carbon in water treatment and its techniques for its development, with the premise of analyzing the potential of Activated Carbon (AC) in the treatment of water for human consumption. For this end, it aims to identify the techniques used for the production of $\mathrm{AC}$, use and its benefits, production from vegetable waste for water treatment. Activated carbon has the ability to selectively collect gases, liquids and impurities inside its pores, which is the reason it is widely used in filtration systems and for that the treatment of water, the coal fulfills the function of adsorbent, retaining in its pores certain types of impurities: large particles that cause undesirable color, taste or odor in the water. In the treatment of effluents, coal is used for clarification, deodorization and purification of effluents.
\end{abstract}

\section{Keywords}

Activated Carbon, Water Treatment, Techniques Used

\section{Introduction}

In the 19th century, the first reports of experiments in public appeared, demonstrating the ability of activated carbon to neutralize potentially lethal poisons. Coal was already described by several ancient peoples, such as Egyptians and Greeks, and its effects in combating intoxication were also known to American Indians [1]. Activated charcoal (CA) is a material obtained from the controlled 
burning of certain types of wood, and can be made from coconut shells and other vegetable residues, as well as cork remnants. It is a very porous material, with excellent filtration, deodorization and removal of toxic and radioactive substances, being widely used in the chemical, food, pharmaceutical industry, in water filtration and purification systems [2].

In addition, it is formed mainly by carbon, being very porous, with a large contact surface, widely used as catalyst support and to purify gases and liquids through adsorption, which consists of retaining molecules, including heavy metals, in their surface pores. The use of activated carbon to remove harmful impurities, whether in the treatment of water or air, is essential [3].

There are two ways to activate coal, one physical and one chemical. The various activation processes are, in the great majority, variations of a basic procedure which is the carbonization or pyrolysis of the raw material. There are also three basic physical forms of activated carbon: powdered (powder), granulated and pelletized.

Thus, the characteristics of activated carbon depend on the raw material used (vegetable or mineral) and the activation process (chemical or physical). As a result, each process will have different adsorption properties and different uses [3]. Despite being an ideal material for the removal of contaminants, the use of activated carbon is limited due to its high production cost, which has enabled new research with more viable options for reducing production costs. One of these options would be through the use of biomass as an alternative precursor material to conventional methods of producing activated carbon that currently uses mineral coal [4] [5].

This work aims to provide an overview of the methodologies used in the studies of activated carbon in the treatment of water for human consumption, a study of the state of the art and its techniques used for its development. Thus, the discussion proposed here may contribute to broadening the discussion on this type of research.

\section{Existing Techniques for the Production of Activated Carbon}

The production of activated carbon starts with the dehydration of raw materials and carbonization, followed by activation, which increases the diameter of the pores and creates others. Depending on the raw material and the method used, different types of activated carbon are obtained, for different uses. Activated carbon has in its structure a large porous surface area and, still on that surface, are the functional adsorbent materials [6].

The first stage of preparation of an activated carbon is carbonization, which is usually carried out in the absence of air at temperatures of $400^{\circ} \mathrm{C}$ to $800^{\circ} \mathrm{C}$. During the carbonization of the raw material, the condensation of aromatic polynuclear compounds occurs and the breakdown of the groups of the chemical chain resulting in a carbon residue. In this medium, linked cross reactions occur that inhibit the development of the pre-graphite structure [7]. In the activation 
of the coals, two methods can be used: activation by chemical process or activation by physical process.

In chemical activation (Figure 1), carbonization and activation occur in a single step, in which the plant precursor impregnated with a suitable chemical agent is carbonized. The great advantage of chemical activation is related to the low energy cost, temperatures in the range of $400^{\circ} \mathrm{C}$ to $800^{\circ} \mathrm{C}$ and high process efficiency [8]. The advantage of chemical activation is that it provides activated carbon with a larger contact area and more developed pores, unlike thermal activation, where the resulting carbon has a smaller area, which reduces the surface that will be used for adsorption [9].

On the other hand, the physical method (Figure 1) can also be used, being able to be carried out in a single equipment with two consecutive steps. The obtained coal is exposed to the atmosphere saturated with gas or inert vapor, at high temperatures, culminating in a final product with a developed and accessible internal porous structure [7].

Likewise, the physical activation method, even though it does not occur in a single step, is less costly, in addition to causing less environmental impact, given the inert characteristics of the gases used and the non-use of chemical agents, such as acids and bases [10]. In physical activation, the temperature variation is used to carbonize the precursor using purging gases such as $\mathrm{CO}_{2}$ to eliminate the $\mathrm{H}_{2} \mathrm{O}$ vapor produced in the precursor carbonization reaction. With the loss of $\mathrm{H}_{2} \mathrm{O}$, the precursor becomes physically activated at high temperatures [11].

\section{Use of Activated Carbon and Its Benefits}

Activated carbon is one of the most widely used adsorbents worldwide in the treatment of water and aqueous waste. It can be said that coal, without activation, was used by Scheele since 1773 in the treatment of gases. It was also used in natural coal to decolorize aqueous solutions in 1786 and was responsible for carrying out the first quantification of the adsorptive power of coal in the liquid phase. Commercially viable activated carbon appeared in the early 20th century with the Swedish scientist von Ostreijko, who obtained two patents in 1900 and in 1901. These patents contained the basic concepts about chemical and physical activation, the latter also called thermal [12].

Chemical Activation

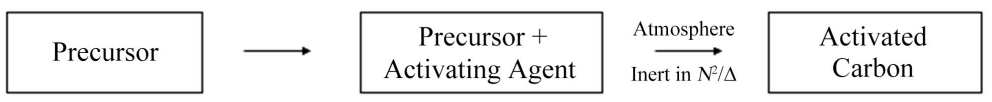

Physical Activation

\begin{tabular}{|c|c|c|c|c|}
\hline Precursor & $\Delta$ & $\begin{array}{c}\text { Precursor } \\
\text { Carbonized }\end{array}$ & $\begin{array}{l}\text { Gas } \stackrel{\mathrm{CO}_{2} \text { and } / \text { or }}{\longrightarrow} \\
\text { Steam from } \mathrm{H}_{2} \mathrm{O}\end{array}$ & $\begin{array}{c}\text { Activated } \\
\text { Carbon }\end{array}$ \\
\hline
\end{tabular}

Figure 1. Demonstrative scheme of chemical and physical activation. Source: Adapted PEREIRA, 2010 [11]. 
Activated charcoal is a porous substance derived from organic material, usually woody and fibrous material. The useful aspect of activated carbon is that it can filter contaminants from water and air, which makes it an important substance in the filtration system. The raw materials used to obtain activated carbon are almost exclusively of vegetable origin and have high carbon power, such as coconut shell, mineral coal, wood, animal bones, agro-industrial residues, olive stone, chestnut hedgehog, among others.

Also, activated carbons are porous carbonaceous materials that have a microcrystalline, non-graphitic form, which have undergone processing to increase internal porosity. Once activated, the coal has an internal porosity comparable to a network of tunnels that branch into smaller channels, and so on. This differentiated porosity is classified according to the size in macro, meso and microporosity [13].

Thus, activated carbons are carbonaceous materials qualified for their high surface area and highly developed porous structure [14]. The choice of the precursor and the activation conditions give us the possibility to design activated carbon for different applications. Recently, they are widely used in a range of applications, such as medical uses, removal of pollutants and odors, gas separation, support for catalysts and water purification, among others [15].

There are three main forms of activated carbon, Granular Activated Carbon, which is irregularly shaped particles with sizes ranging from 0.2 to $5 \mathrm{~mm}$, and is used in liquid and gas phase applications. Powder Activated Carbon, is pulverized coal with a predominantly smaller size than $0.18 \mathrm{~mm}$, they are mainly used in applications in the liquid phase and in the treatment of flue gases. And pelleted activated carbon undergoes a hot extrusion process and is homogenized at an average diameter of $4 \mathrm{~mm}$. They are mainly used for gas phase applications due to their low pressure drop, high mechanical strength and low dust content [16].

In this sense, powdered activated carbon and granular activated carbon are the most used for the treatment of wastewater or to make water drinkable, mainly for the removal of low molecular weight compounds. However, one of the problems found in the application of the adsorption processes to the water treatment is the slow intra-particular diffusion in granular adsorbents, such as granular. On the other hand, powder provides faster adsorption speeds, but the difficulty in handling it limits its industrial use.

Activated carbon is a material with high adsorption capacity, being quite effective and generally used in the treatment of drinking water, however, the manufacture of adsorbents of this type requires a high cost considering the origin of the raw material [17]. Considering this, there is a disadvantage that is losses during the process of recovering the adsorbents, often becoming inopportune. Through this perspective, there is a great scientific interest in the search for low-cost materials that can be used for the production of activated carbon, which is the case of biological waste, such as biomass [18]. 
Therefore, activated carbon through biological materials stands out for being a low-cost and abundant material in the region and that can be used for the treatment and control of pollutant emissions, purification process, gas storage, catalysts, catalytic supports, in deodorization, separation, detoxification, etc. [19]. Even though it is of low cost, it is still a material of very limited use, as it has a disadvantage that is in the preparation of charcoal, in which the production process in lignocellulosic materials generally requires high temperatures, going to over $700^{\circ} \mathrm{C}$.

\section{Production of Activated Coal from Vegetable Waste}

Activated carbon eliminates substances of varying concentration, composition and size [20]. This material has multiple applications and has been used in the food, beverage, pharmaceutical, chemical, etc. industries. In the treatment of water for human consumption, activated carbon has the ability to eliminate the taste and odor of water, to eliminate contaminants such as heavy metals, toxic gases and pesticides, to reduce natural organic matter, thus limiting the formation of by-products of as much as possible, disinfection and/or oxidation, such as trihalomethanes [21] [22].

Therefore, each material will determine the predominant characteristics of activated carbon, such as the diameter and presence of pores. Activated charcoal can be made from coconut shells, but also from cork remnants, a very porous material, with excellent characteristics in the field of filtration, deodorization and removal of radioactive and toxic materials. It also works as a source of coal for burning bovine bones at high temperatures, being known as bone coal [6].

As a consequence, the Amazon is characterized by a great diversity of species that produce residues that have not yet been studied in terms of their industrial use. Products such as Barca de Cupuaçu, Açaí and Ouriço da Castanha do Brasil can originate activated carbon with high quality, good yield and low cost, replacing the chemical adsorbents currently used by industries [23]. Similarly, plant residues from the Amazon have been shown to be important precursor materials for the production of activated carbon, since they are renewable, generally available in large quantities and at low cost when compared to other precursor materials.

With regard to characteristics, a good precursor material is one that has a high carbon content in its composition, such as rice, nutshells, mineral coals, wood, animal bones, fruit stones, coffee beans, among others. The precursors of activated carbon are materials that enrich themselves during heat treatment, without melting or slowing down that prevents the formation of micropores. If the porosity of the precursors is low, it is necessary to activate them [13].

Accordingly, biomass consists of organic material of animal or vegetable origin and is considered an alternative source of energy. Agricultural waste has a high energy potential, since after carbonization, biomass is transformed into charcoal [24] [25]. 
In many countries, biomasses are used to produce activated carbon, as an example, in Angola one of the biomasses used for the production of active charcoal is African Baobab is a natural fibrous biomass, which is used as a precursor to produce custom-made activated carbon for pollutant removal in water courses. The precursors used are Baobá residues, namely bark, wood and seeds, collected in Angola. It shows the adequacy of the use of Baobá residues in the production of activated carbon, which can be considered a new path for the valorization of its residues, with good adsorption properties [26].

Also, the "hedgehog" bark has a high lignocellulose content, which can qualify this material because it has physical characteristics in its constitution that favor obtaining a good quality charcoal and another important factor is the fact that the "hedgehog" bark hedgehog is considered to be waste from the Brazil nut production chain, and therefore has a low acquisition cost [27]. Likewise, vegetable fibers (such as coconut or jute) can be good precursors for the production of porous activated fibers by simple preparation methods. Depending on the nature of the crude fiber, the treatment conditions and the activating agent, several types of fibrous activated carbon can be obtained [3].

Carmona analyzed the energy potential of biomass and charcoal from residues produced from the commercial extraction of Brazil nuts. For this, he applied the carbonization method to immediate chemical analyzes. Among the results, both the hedgehog and the tegument of Castanha-do-Pará transformed into charcoal have the potential to be used for energy purposes. Thus, such residues present favorable characteristics for this purpose, some of which are even similar or superior to those presented by woods of other species [28].

Likewise, with the açaí stone, which has a high carbon content and the produced charcoal has a heterogeneous surface with pores of different sizes, in this way the açaí stone has the potential to produce activated charcoal [29]. Because the charcoal is produced from the fruit's mesocarp, it does not cause damage to the environment, being an efficient and ecologically correct method [19].

Likewise, [30] who produced and evaluated the quality of activated carbon obtained from coconut endocarp (Cocos nucifera) and applied it to adsorption of the methylene blue dye present in aqueous medium, was prepared by physical activation, using water vapor as an activating agent. Then, characterizations related to gravimetric yield on activated carbon (RGCA), thermogravimetric analysis, surface area (SBET), pore volume and diameter and scanning electron microscopy were performed. To assess the adsorptive capacity, studies of kinetics and adsorption isotherms were carried out, and the Langmuir and Freundlich isotherm models were applied. The coconut endocarp produced an activated carbon of excellent quality, which can be used as an adsorbent of dyes in aqueous medium.

That said, the use of vegetable residues is a sustainable alternative in the preparation of activated charcoal, since using residual materials such as fruit peels, broccoli stems, avocado peels or seeds, chestnuts and hedgehogs, in addition to 
many others, reduces the generation of solid waste. In addition, by carefully controlling the conditions of activation and carbonization, it is possible to prepare activated carbon with specific high surface areas that have been shown to be highly efficient in eliminating organic and inorganic compounds present in wastewater, such as dyes and heavy metals, respectively [3].

\section{Activated Carbon in Water Treatment}

In the 1960-1970s, Western developed countries began using activated carbon technology to treat drinking water to improve the removal of organic contaminants. Also, the activated carbon process has become the main advanced water treatment process, which is commonly used in developed countries, such as America, Japan, the Netherlands, Switzerland, among others [27]. Activated carbon is widely used in water treatment due to its high adsorbent capacity [8]. This product is generally used worldwide for wastewater treatment, drinking water, gas purification and as a catalyst support [31].

Likewise, activated carbon is widely used in wastewater treatment. Usually obtained from lignocellulosic materials, such as wood, coconut husks, rice, sugarcane bagasse and among others, activated carbon has a large porous development that allows it to be one of the most versatile adsorbents ever used [32]. However, due to its high efficiency, adsorption with activated carbon is recognized as the best control technology for the treatment of water, so that water purification is the main application of this adsorbent [33] [34].

In view of this, water treatment is divided into eight stages (Figure 2): 1) Catchment: which consists of removing water from water sources or reservoirs; 2) Adduction: it is the transport of water from the springs to the treatment; 3 ) Coagulation: in this process, existing impurities whose particles are small will be treated; 4) Flocculation: in which the water is subjected to mechanical agitation, so that the impurities form larger and heavier flakes; 5) Decantation: which is the separation, by means of gravity, of sedimentable solids; 6) Filtration: pass the water through filters formed by layers of coarse sand, fine sand, gravel, gravel and activated carbon; 7) Disinfection: the water is added with chlorine, fluorine and PH control; 8) Reservation: water is stored in reservoirs [35].

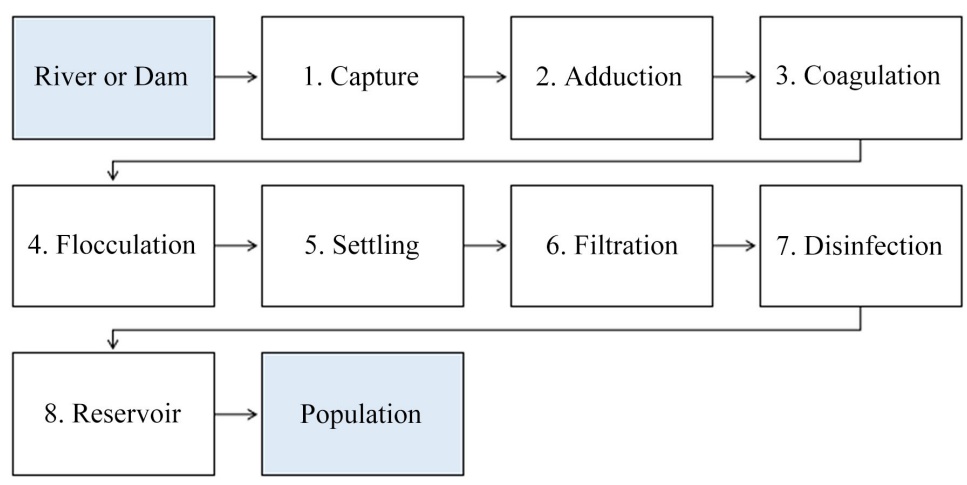

Figure 2. Stages of water treatment using activated carbon. Source: Autor. 
The treatment of activated carbon in water treatment plants is usually installed to provide the removal of natural organic compounds, flavor and odor compounds and synthetic organic chemicals. The adsorption of activated carbon physically connects gas or liquid phase molecules to the surface of the activated carbon. Activated carbon is an efficient adsorbent, as it is a highly porous material and provides a long surface area on which contaminants can adsorb [16].

[36] Investigated the production and use of activated carbon, derived from the Brazil nut shell, as a means of de-fluoridation of drinking water. In view of this, the production consisted of carbonizing the Brazil nut shell in an oven with the presence of nitrogen $\left(\mathrm{N}_{2}\right)$ at a heating rate of $8^{\circ} \mathrm{C} / \mathrm{min}$ until reaching $700^{\circ} \mathrm{C}$. The material was kept for 2 hours at this temperature. The results showed that activated carbon from Brazil nut derivatives has the potential to be used as a biosorbent for the de-fluoridation of water supply [37].

In short, activated carbon is a powerful adsorbent used prolifically during water purification efforts to remove contaminants and unwanted components. Although activated carbon can be used in a wide range of water treatment applications, it is a critical tool used in all municipal and industrial water treatment facilities to treat drinking water, effluents and water for use in processes.

\section{Conclusion}

In the days in which we live and are approaching, chemical processes need to be treated responsibly and fit in the search for sustainability, reducing environmental impacts. Direct actions in the water, air, regeneration and recycling sectors are urgent. In this respect, the use of activated carbon to remove harmful impurities, whether in the treatment of water or air, is essential. Thus, the biological treatment of water for human consumption reduces the instability of water, characterized mainly by the presence of organic matter in low concentrations. The benefits of more stable water include the reduction of bacterial growth, the formation of biofilms and corrosion in the distribution network. In addition, the need for disinfectant residues decreases, minimizing the formation of toxic by-products derived from reactions between the disinfectant and organic matter. In view of this, the removal of contaminants from water is indispensable to guarantee the life and make drinking water available. Activated coals from biomass residues are adsorbents with high potential due to the low cost of the precursor that is found in abundance in the Amazon. Several studies on activated carbon emphasize the great potential that it generates in the solution for treatments in waters contaminated with different types of contaminants. However, it is still necessary to carry out a large-scale study in relation to activated carbon of biomass residues, since it is a range of precursors that can be used both in industry and in the daily life of humans. In general, it is expected that the world will be able to use the products of biomass residues as some works mentioned in this article for the production of activated carbon in a sustainable and clean way, in order to promote the culture of reuse in the production sector of the sustainable activated carbon. 


\section{Acknowledgements}

The present review had resources from the Ministry of Science, Technology, Innovations and Communications-MCTIC (acronym in Portuguese). The authors would like to thank the National Institute for Research in the Amazon-INPA, Rede BIONORTE and the Federal University of Amazonas (UFAM) for the partnership. Scientific research in doctoral research was by the first author.

\section{Conflicts of Interest}

The authors declare no conflicts of interest regarding the publication of this paper.

\section{References}

[1] Freitas, L. and Bueno, S.M. (2014) Carvão Ativo: Breve Histórico e Estudo de Sua Eficiência na Retenção de Fármacos. Revista Científica Unilago, 1, 2.

[2] Ecycle (2021) Carvão ativado: Usos e cuidados. https://www.ecycle.com.br/6914-carvao-ativado.html

[3] Tamanna, K., Hasan, Md.S. and Priyanka, D. (2016) Applicability of Activated Carbon Filtration in Surface Water Treatment. Asian Journal of Innovative Research in Science, Engineering, and Technology, 1, 1-6.

[4] Danish, M. and Ahmad, T. (2018) A Review on Utilization of Wood Biomass as a Sustainable Precursor for Activated Carbon Production and Application. Renewable and Sustainable Energy Reviews, 87, 1-21. https://doi.org/10.1016/j.rser.2018.02.003

[5] González-García, P. (2018) Activated Carbon from Lignocellulosics Precursors: A Review of the Synthesis Methods, Characterization Techniques and Applications. Renewable and Sustainable Energy Reviews, 82, 1393-1414. https://doi.org/10.1016/j.rser.2017.04.117

[6] Reinoso, F.R. (2004) Adsorbentesenlasolución de algunos problemas ambientales. Ediciones CYTED, Madrid.

[7] Shoaib, M. and Al-Swaidan, H.M. (2015) Optimization and Characterization of Sliced Activated Carbon Prepared from Date Palm Tree Fronds by Physical Activation. Biomass and Bioenergy, 73, 124-134. https://doi.org/10.1016/j.biombioe.2014.12.016

[8] Portal Tratamento de Água. (2021) Uso eficiente do carvão ativado como meio filtrante em processos industriais.

https://tratamentodeagua.com.br/artigo/uso-eficiente-do-carvao-ativado-como-mei o-filtrante-em-processos-industriais

[9] João, M.V.N., Carlos, E.C.L., Carrott, P.J.M. and Carrott, M.M.L.R. (2011) Production of Activated Carbons from Almond Shell. Fuel Processing Technology, 92, 234-240. https://doi.org/10.1016/j.fuproc.2010.03.024

[10] Mab, R. (2005) Ion removal Cr(III) from Aqueous Solutions by Adsorption on Activated Carbon and Biosorption and Immobilized Yeast. Master's Thesis, Federal University of Pará, Brazil.

[11] Pereira, E., Oliveira, L.C.A., Vallone, A., Sapag, K. and Pereira, M. (2008) Preparação de Carvão Ativado em Baixas Temperaturas de Carbonização a Partir de Rejeitos de Café: Utilização de $\mathrm{FeCl}_{3}$ Como Agente Ativante. Química Nova, 31, 1296-1300. 
https://doi.org/10.1590/S0100-40422008000600004

[12] Bhatnagar, A., Hogland, W., Marques, M. and Sillanpää, M. (2013) An Overview of the Modification Methods of Activated Carbon for Its Water Treatment Applications. Chemical Engineering Journal, 219, 499-511. https://doi.org/10.1016/j.cej.2012.12.038

[13] Claudino, A. (2003) Preparação de carvão ativado a partir de turfa e sua utilização na remoção de poluentes. 101 f. Dissertação, Mestrado em Engenharia Química, Universidade Federal de Santa Catarina, Florianópolis. http://repositorio.ufsc.br/xmlui/handle/123456789/86346

[14] Hasan, R. (2015) Ways of Saying: Ways of Meaning: Selected Papers of Ruqaiya Hasan. Bloomsbury Publishing, London.

[15] Werther, J., Saenger, M., Hartge, E.-U., Ogada, T. and Siagi, Z. (2000) Combustion of Agricultural Residues. Progress in Energy and Combustion Science, 26, 1-27. https://doi.org/10.1016/S0360-1285(99)00005-2

[16] NaturalTec (2021) Carvão Ativado-Ficha Técnica. https://www.naturaltec.com.br/carvao-ativado-ficha-tecnica/

[17] Baccar, R., Bouzid, J., Feki, M. and Montiel, A. (2009) Preparation of Activated Carbon from Tunisian Olive-Waste Cakes and Its Application for Adsorption of Heavy Metal Ions. Journal of Hazardous Materials, 162, 1522-1529. https://doi.org/10.1016/j.jhazmat.2008.06.041

[18] Gonçalves, M. (2008) Preparação de carvão ativado e impregnação com ferro ou cromo para aplicações em processos de descontaminação ambiental. Tese de Doutorado, Programa de Pós-graduação em Agroquímica, Universidade Federal de Lavras, City of Lavras, Minas Gerais.

[19] Nogueira, R.M., Ruffato, S., Carneiro, J.S., Pires, E.M. and De Alvares, V.S. (2014) Avaliação da carbonização do ouriço da Castanha-do-Brasil em forno tipo tambor. Scientific Electronic Archives, 6, 7-17. http://www.alice.cnptia.embrapa.br/alice/handle/doc/1004208

[20] De Pereira, S.F.P, Maciel, A.E.S., Dos Santos, D.C., Mares, E.K.L., Oliveira, G.R., Bittencourt, J.A. and Da Oliveira, J.S. (2014) Remoção de Metais de Águas Superficiais Usando Carvão Vegetal de Açaí (Euterpe Oleracea Mart). Proceedings of International Conference on Engineering and Technology Education, Guimarães, 16-19 March 2014, 397-401.

[21] Aksu, Z., Tatli, A.İ. and Tunç, Ö. (2008) A Comparative Adsorption/Biosorption Study of Acid Blue 161: Effect of Temperature on Equilibrium and Kinetic Parameters. Chemical Engineering Journal, 142, 23-39. https://doi.org/10.1016/j.cej.2007.11.005

[22] Jin, P., Jin, X., Wang, X., Feng, Y. and Wang, X.C. (2013) Biological Activated Carbon Treatment Process for Advanced Water and Wastewater Treatment. In: Biomass Now-Cultivation and Utilization, IntechOpen, London, 153-192. https://doi.org/10.5772/52021

[23] Cruz J.O.F. (2010) Produção de carvão ativado a partir de produtos residuais de espécies nativas da Região Amazônica. Programa de Pós-Graduação em Engenharia Mecânica e de Materiais, Universidade Tecnológica Federal do Paraná, Curitiba, 62-71.

[24] Inovativa-Revista Eletrônica do Instituto Nacional de Tecnologia Ano 4, No. 18-Janeiro|Fevereiro de 2017.

[25] Pereira, E.I. (2010) Produção de carvão ativado a partir de diferentes precursores utilizando $\mathrm{FeCl}_{3}$ como agente ativante. Programa de PósGraduação em Agroquímica, 
Universidade Federal de Lavras, City of Lavras, Minas Gerais, 72.

[26] Saini, R.K., Nile, S.H. and Park, S.W. (2015) Carotenoids from Fruits and Vegetables: Chemistry, Analysis, Occurrence, Bioavailability and Biological Activities. Food Research International, 76, 735-750. https://doi.org/10.1016/j.foodres.2015.07.047

[27] Tchikuala, E., Mourão, P. and Nabais, J. (2017) Valorisation of Natural Fibres from African Baobab Wastes by the Production of Activated Carbons for Adsorption of Diuron. Procedia Engineering, 200, 399-407. https://doi.org/10.1016/j.proeng.2017.07.056

[28] Carmona, I.N., Da Sampaio, J.S., Andrade, F.W.C., Júnior, C.D.C., De Junior, S.M.O.M., Da Moreira, L.S. and Moutinho, V.H.P. (2017) Potencial energético da biomassa e carvão vegetal de resíduos de Castanha-do-pará (Bertholletia excelsa Bonpl.). Congresso Brasileiro de Ciência e Tecnologia da Madeira.

[29] Berni, J.V, De Cesaro, J.P.V, Scheufelle, F.B. and Vieira, M.F. (2018) Produção e Caracterização de Carvão Ativado Proveniente do Caroço de Açaí. In: São Paulo: Blucher, Editora Edgard Blucher Ltda., São Paulo, 3100-3103. https://doi.org/10.5151/cobeq2018-PT.0821

[30] De Morais, M.R., Santana, G.M., Lelis, R.C.C. and Paes, J.B. (2019) Produção de Carvão Ativado Microporoso com Vapor D’água Preparado a Partir de Endocarpo de Coco (Cocos nucifera). Advances in Forestry Science, 6, 699-703. https://doi.org/10.34062/afs.v6i3.6717

[31] De Oliveira, L.R. (2014) Remoção De Alumínio Em Sistema Contínuo Por Adsorção Em Coluna De Leito Fixo Com Carvão Ativado. Dissertação de Mestrado, Programa de Pós-graduação em Engenharia Química, UFU.

[32] Phan, N.H., Sebastien, R., Catherine, F., Laurence, L.C., Pierre, L.C. and Thanh, H.N. (2006) Production of Fibrous Activated Carbons from Natural Cellulose (Jute, Coconut) Fibers for Water Treatment Applications. Carbon, 44, 2569-2577. https://doi.org/10.1016/j.carbon.2006.05.048

[33] Cheng, W., Dastgheib, S.A. and Karanfil, T. (2005) Adsorption of Dissolved Natural Organic Matter by Modified Activated Carbons. Water Research, 39, 2281-2290. https://doi.org/10.1016/j.watres.2005.01.031

[34] Hamdaoui, O. and Naffrechow, E. (2007) Modeling of Adsorption Isotherms of Phenol and Chlorofenols onto Granular Activated Carbon. Part I. Two-Parameter Models and Equations Allowing Determination of Thermodynamic Parameters. Journal of Hazardous Materials, 147, 381-394. https://doi.org/10.1016/j.jhazmat.2007.01.021

[35] Snatural (2021) Carvão Ativado para Filtração de Água e Ar. https://www.snatural.com.br/carvao-ativado-filtracao-agua-ar/

[36] Valença, R.M., et al. (2017) Adsorção de Fluoreto em Solução Aquosa e em Água de Abastecimento em Carvão Ativado à Base de Casca de Castanha-do-Brasil. Engenharia Ambiental: Pesquisa e Tecnologia, 14.

[37] Trata Brasil (2021) Venha Conhecer as Etapas para o Tratamento de Água. http://www.tratabrasil.org.br/blog/2019/04/18/venha-conhecer-as-etapas-para-o-tra tamento-de-agua/ 